\title{
CHINESE ECONOMIC SUCCESS - INSPIRATION FOR ECONOMY, POLICY AND SECURITY
}

This paper focuses on the recent changes in global economic relations and increase of China's importance in global politics, security and economy. It describes the changes in China's security, economic, political strategy and its influence to its own development and empowering its position in international economic, political and security relations. The implications for the EU security management are described, too.

Keywords: China, economic security, sustainable development, soft power, strategic investments, Africa

\section{Introduction}

Nowadays, there are several serious turbulences and breakings of an economic, social, political, and security balance of the world economic system. We live in a difficult period of global economic, political and security order transition. This, together with acceleration of scientific improvement as well as with increasing complexity of multidimensional structure of risks and threats, is source of need for taking predictive strategic (economic, environmental, social, security and political) decisions related to the future development of global economy.

It is possible to state that the disintegration of the socialistic block, the end of the cold war, and the end of bipolar world order can be seen as the causes of necessity for the separated states and integration units to take transition:

- from existing, operation and development in somehow limiting, but very stable environment from an economic and security balance point of view,

- towards the existing, operation, and development in very unstable conditions of transitioning world economy.

This creates a requirement for a development of new socioeconomic and security strategies on a national or international (union) level.

\section{Actual Changes in Global Economy Related to the Political Economic and Security Position of State in Global Economic Space}

It is possible to identify a significant trend to transition from bipolar world economy and security towards multipolar one, within the evaluating of present state of global economy and policy. Fol-

\footnotetext{
* Milos Ondrusek

Department of Crisis Management, Faculty of Special Engineering, University of Zilina, Slovakia, E-mail: Milos.Ondrusek@fsi.uniza.sk
}

lowing theoretical options of future world order can be identified: unipolarity, bipolarity and multipolar development of the world.

It is possible to take into the account these theoretical possibilities as the result of present global economic, political and security transition:

- Unipolarity (that means a dominant position of one country or integration unit, which is perceived as hegemonic or dominant key player of international economics, politics and security in the world global economy.)

- Bipolarity (that means an existence of dominant positions of two countries or integration units, which are perceived as dominant key players of international economic, political and security relations in the world. The development of both of them guarantees the social, economic, political and security balance of the world )

- Multipolarity - (that means an existence of several - (more than two) dominant centers of social-economic and security development. This creates a dynamic balance by the necessity of interactions with the other centers. This reduces bad sides of monopoly or semi monopoly situations in dividing world economic, political and security power.)

In relation to the presumption of unipolarity it is possible to say that in present state of world economic system influenced by the weakening of the US position there hardly exists a prognosis about a recovering its position of world hegemony or about the changing this position with another possible the most powerful country in future world development. It is caused mainly by the polycentric character of world socio-economic development. The most realistic presumption of being the most important country with principal influence to the global economy and policy says about potential of China or India or European Union. But Chinese huge economic development is not connected with the same level of development in the other areas of national social economic system. Problems can be identified in relative political isolation, in sustain- 
ability of the current rates of economic development because of the high level of energetic and raw materials demand of Chinese economy, social area, and demographic imbalance caused the one child policy preferred by the Chinese authorities in the second half of the $20^{\text {th }}$ century. Problems in future development of India can be viewed in the lack of institutional and democracy development.

Returning to the bipolar order in global economy seems to be unlikely because of current state of global economy development with significant trend of arising several new significant centers of social-economic development, (for example an Asian new core of dynamic developing East Asian countries, China, India and the other countries called Asian dragons or tigers).

The most likely looks the variant of multipolar future economic, political and security world order with several relatively equivalent centers of social and economic development and political and security power. This implicates many new-dimensional restructured risks for the social-economic-political and security stability of the world economic system. The Key fact that the present transition of the world towards a polycentric world economy system order has not been finished yet, seems to be the most important.

It is just uncertainty and complexity, variability, and instability of current conditions of re-structuralizing international economic political and security relations, which are creating new serious challenges for countries and integration units in relation to the setting up their future economic, political and security position in the frame of future global economy development.

From the security and crisis management point of view it can be stated that nowadays we are in the period impacted by the forming of future national security positions as well as forming the world security order by utilization long term stability and development factors of key areas of economy, policy, security in current unstable conditions of the world economic system.

The process of creation and forming the economic, national political and security position is in current state of world economic system influenced by:

- incomplete transition of world economic system from bipolar to polycentric order one,

- overcoming differences and borders of an autonomous seizing and position of single key national areas of operation and management in the global environment,

- increase of the complexity and multidimensionality of various real or potential determinants of future country development,

- increase of number, complexity, and interdependent multidimensional character of present risks as well as risks of future development of global economy together with development of the country or integration unit's position within it.

- impacts of global trends e. g. increase of regional disparities, decrease of ecological balance of environment, development of transport and IT technologies, acceleration of scientific development

This implicates the fact that nowadays it is neither possible nor effective to solve the key areas and problems of state existence in international environment separately without considering the synergic impact of the other ones. This is setting the need of change in seizing the basic aim of country existence and also the existence of its key subsystems.

The priority should not be seen in the maximization of growth in key indicators of a national development but its stability and future sustainability together with consideration of present and future threats of sustainable socio-economic national development. It is clear that in present state of globalization it is not possible to solve the economic affairs without considering the policy, security, ecology, etc. It is just an increase of complexity, which is the powerful stimulus for development of new security concepts as well as new conceptions of national development considering the recent changes in basic characteristics of global economic space. From this point of view it is just an economic strength and potential of sustainable development which create and enforce the national long term stability and security. Military way of securing the state security has been becoming inefficient. We can identify the increase of using the economic tools for securing the strategic security goals and objectives.

\section{Strategic Investments in Africa - Important Component of an Economic Security Strategy of China}

Former mentioned factors are in many countries main drivers of reevaluating their strategic activities in relation to their future security - economic and political position in global context of the world economic system.

China can be considered a significant representative of mentioned changes in seizing the concept of state development.

In context of recent changes in global economy, it is possible to state that China underwent serious, important changes in seizing its own strategic position and the priorities. It is in the process of developing its position in the global economy. Briefly, it is possible to depict the basic frame of mentioned changes in these points.

- Transition from absolutistic state directing internationally isolated economy towards relatively closed state centrally directed economy with increasing features of market economy.

- Transition from preference of military approach to prevention and solving of security affairs towards preference of soft power and economic tools using in international affairs and also in security affairs as a principal component of its own wider seized security strategy.

As a proof of outlined changes can be seized a long term high rates of economic development, incorporation of China to WTO and the other international structures, as well as developing China's economic and security position in the global economy.

Recenty we can identify three basic tendencies in Chinese using of economic tools to enforce its own multidimensionally seized security and politic position in global economy: 
Growth of Real GDP of China in selected years compiled by author based on data of IMF[1]

Table 1

\begin{tabular}{|c|c|c|c|c|c|c|c|}
\hline Year & 2005 & 2006 & 2007 & 2008 & 2009 & 2010 & $\begin{array}{c}2011 \\
\text { (projected by IMF) }\end{array}$ \\
\hline Growth of Real GDP & $11.3 \%$ & $12.7 \%$ & $14.2 \%$ & $9.6 \%$ & $9.1 \%$ & $10.5 \%$ & $9.6 \%$ \\
\hline
\end{tabular}

- using the pro-export oriented foreign trade policy together with under valuating currency policy of Chinese currency, all this is focused on the supporting of Chinese exporters,

- gathering or reducing huge amounts of dollar reserves considering the economic and security priorities of China in relation to the China vs. US foreign policy objectives,

- trying to develop foreign trade relations with an African and Latino-American and Asian countries focused especially to securing cheap raw materials in long term horizon for high energetic demand of Chinese economy. There exists a tendency to achieve this objective through exchanging the long term mining concessions or permits for realization of huge infrastructural projects by Chinese firms in African and Latino-American states.

Recent economic development affected by present financialeconomic crisis causes a decreasing advantage of cheap Chinese Juan. It is because of serious global demand failing. Principally, this strategy is guaranteeing economic success of Chinese exporters within the frame of recent rules, and level of international trade relations' liberalization.

Level and way of using the dollar reserves seems in recent situation of wakening USA currency position to be the controversial tool. It can be a source of Chinese pressure to USA and its foreign trade partners aimed to the correction of their activities in relation to the Chinese foreign trade policy and security interests. From the China's point of view there exists a real risk of appreciation of Chinese currency and distortion of Chinese economic proportions, or decreasing of US dept by using smart monetary policy focused to decreasing US dollar exchange rate. Another notable feature of Chinese economic and security strategy are efforts to achieve the increase of Chinese impact to the international policy and security thank to the Chinese strong international trade position on the global market.

It is best noticeable in the increasing amount of bilateral exclusive profitable trade partnerships with African and Latino American states.

The African continent seems to be a base of future long term economic development of China.

Although we can identify a Chinese demand for raw materials from the other less developed countries, we can state that Africa is the number one. It is documented by:" The chairperson of the Commission of the African Union, Jean Ping, commended China in January 2009 for its contributions to Africa and identified China as Africa's key strategic partner [2].

It seems to be the Chinese priority to establish a long term and stable social - economic and political relations among the
China and African states It can be seen as the attempt of China to create a long term partnership as the guarantee of the social, economic, political and security development for both partners China and Africa too.

There are a lot of economic political strategic activities among the China and African states, which are not aimed only to the short term securing the exchange cheap African raw materials to the low rated loans or big infrastructure construction sites.

Chinese activities in Africa are wider. For example: In February 2009,China dramatically broadened its diplomatic support for Africa at a plenary session of the UN General Assembly, during which the Chinese ambassador declared: "In the reform of the Security Council, priority should be given to the greater representation of developing countries, in particular African ones” [3].

More African students now attend school in China than ever before (5,900 in 2007), most on Chinese-government-provided scholarships. China has pledged to "double the number of such scholarships by 2011" [4].

China has expanded the list of duty-free imports fromAfrica from 190 to 440 items and is discussing a free-trade agreement with the Southern Africa CustomsUnion. Trade relations are further fostered by "commercial counselor offices in 40 African countries and seven consulates-general in five of them [4].

As proof of increasing importance of trade partnerships among the China and African states in China's foreign trade and security policy can be seen in the following figure

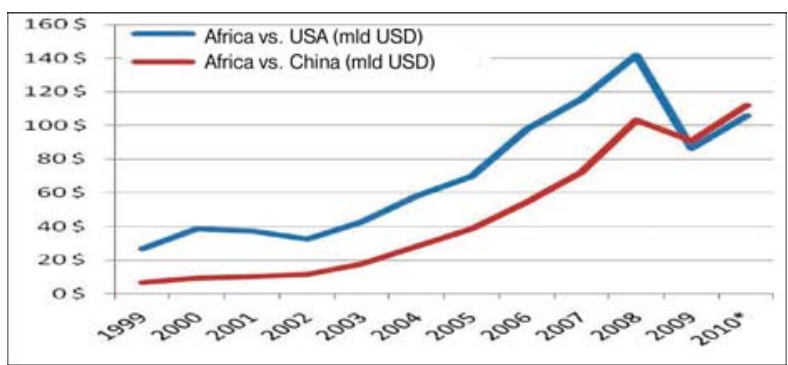

Fig. 1. Trade balance between Africa and China compared to trade balance between Africa and USA [5]

This figure shows development of foreign trade balance between China and African continent in comparison to the same statistics between USA and African continent. In Figure 1 we can see the basic increasing trend of both US and China's trade balance with 
Africa. The most interesting period showed in the figure from our point of view is the period between the years 2008 and 2010 . There can be seen a dramatic change in US vs. Africa trade balance. From the positive extreme increase in 2007, 2008 to huge drop in 2009 and its relative recovering on a lower level in 2009. This caused that China is the second in value of foreign trade with Africa just behind the EU. In the figure it is possible to see the serious impact of breaking recent financial and economic crisis to the US economy and to the US vs China trade relations too.

In the figure 1 it is possible to identify two serious effects. The first is that the recent financial and economic crisis did not affect China crucially. This is caused by the fact that China was not the source country of crisis, next by the fact that China increased its orientation to the national internal market. It helped to decrease an impact of the recent crisis thank to the large scale of China's national market. The second economic efficiency and profitability of Chinese exporters slowed the fall of the traded value between China and Africa.

Taking into account the activities of China and the U.S.A., which are focused on ensuring the future sources of economic development, it can be stated that in the current reality of exhausting natural resources we are witnesses of a fight for raw material base (mostly) from the African continent. Especially ensuring resources for future development of the country is considered as a strategic priority of state security. In the relation to the Chinese-American "fight for Africa (especially for its raw material base)", this is documented e. g. by the rising of Chinese and African trade balance from 6 billion USD in 1992 to 112 billion USD in 2010 [5].

We can observe two different approaches in this fight for the African resources. The U.S.A. tries to promote its interests in Africa through transnational institutions, in which it has a significant position, and its involvement in numerous military conflicts. On the other hand, China tries to promote business partnerships by the creation of long-term contracts based on the exchange of cheap natural resources for building a new infrastructure, with individual African states. This can be viewed as the strategic idea of economic and security strategy. It also can be viewed only as the necessity of Chinese economy because of its huge development and its technological amortization and high energetic intensity ratio. The truth lies somewhere in intersection of these alternatives. It is possible to state increasing importance and impact of China's position in international economics and security.

It has to be said that although the foreign trade balance between the EU and Africa is nearly three-time higher than balance between the Africa and China [5] the European union has a serious problem with structure and non development character of the trade relations and investments in Africa. Notable difference can be seen also in the managing of human resources as the important part of strategic investments in Africa. In comparison to the European Union, China tries to establish a large community of the Chinese people in African states. This is really strategic in relation to the future development of China.
This one will allow to create new markets for Chinese production, it will accelerate the socio-cultural compatibility of both cultures, it will improve the negotiating position against the other states in the strategic talks with African states, it will allow to get the cheap African raw materials and also to export China's social and economic problems to Africa. (For example. export of the Chinese unemployment into the African states. etc.)

\section{Summary}

China is improving its economic and security position by orientation to the non military sources of development. Most of all it is achieving this by the smart using of economic tools for securing its future development. By this, China is significantly empowering its security in the global context. It is worth discussing if China is oriented to the economic security tools using in Africa only for its smart strategy of securing sustainability of its future development or it is only reaction on its recent acute problems in its national scale with dissatisfied demand for energies and raw materials. Long term activities of Chinese economic diplomacy and foreign trade policy are signs of strategic accent of the mentioned priorities of China in Africa or in using tools of economic security to improving its recent and future security too.

China can be thought to be an example of changing a view to the security and economic security in the global context. There can be identified a change from orientation on the securing ability of using military power to defend own economic capacities and interests in time, to the orientation on improving the soft power and economic tools usage. This is aimed to the securing the China's political, security and economic foreign trade position in the global context.

The sustainability of economic growth can be seen as the problematic issue, This is potential problem because of demographical imbalance of Chinese economy, as well as because of the process of arising more than two centers of development in the global economy.

It is clear that in recent world conditions and state of socioeconomic development it is just the using of economic tools to be the important component impacting of strategic development of the states.

At the end we can state the serious impact of Chinese foreign trade activities to the selected African countries. In a long term horizon it is necessary to consider the empowering of China's position in Africa. It is really competitive and dangerous for the energetic and raw material stability of the world.

It is necessary by the effective foreign-trade policy to create opposition to the Chinese imports of cheap African natural sources. It is necessary because of the possibility that the African sources can be used by China for achieving the economic, political and military domination in the global size. 
The activities of China have opened the question of insuring the material, energetic security of EU in a long term perspective. There is also a question of revaluation of the geopolitical priorities of EU arising. Finally it can be stated that this paper correctly shows that rising economic cooperation of China with African states is not a kind of soidarity more developed China with less developed African states as the recall on the period when the China was less developed and isolated country, nearly as poor as present Africa. Mentioned economic activities of China in the African continent are manifestation of clear geopolitical strategy aimed to the arising the China's influence in territory which will be the material base for future economic domination in the period of exploited resources.

It should be a priority of security, and crisis management to insure EU position in recent Fight for Africa by the activating proactive investments processes and restructuralizing its export and import in relation to the long term objectives of sustainable development of the European Union.

\section{References}

[1] IMF.: People Republic of China: International Monetary Fund Country Report No. 10/238 [on-line] [cit 23. 3. 2011] available at: http://www.imf.org/external/pubs/ft/scr/2010/cr10238.pdf.

[2] XINHUA.: AU Chairperson Lauds China's Role in Africa's Infrastructure Development [on-line], cit [21.03.2011] available at: www.china.org.cn/.

[3] XINHUA.: China Calls for Developing Nations' Greater Presence in UNSC [on-line], cit [21.03.2011] available at www.china.org.cn/.

[4] HOFSTEDT T. A.: China in Africa An AFRICOM Response. Naval War College Review Issue 2009/ summer, [on-line], cit [21.03.2011] available at: http://www.usnwc.edu/getattachment/52b59501-ad3e-4d14-a797-5e1351d6bce0/China-in-Africa-AnAFRICOM-Response-Todd-A-Hof.

[5] GREGA, M.: China is Catching up with Europe, Africa!(in Slovak) [on-line], cit [21.03.2011] available at: http://www.kaminvestovat.sk/komentare/3581-cina-dobieha-europu-v-afrike.html.

[6] RASO, M.: BRIC Countries are Competing for an Investments in Africa (in Slovak) [on line], [cit. 11.03.2011] available at: http://hnonline.sk/ekonomika/c1-46618870-krajiny-bric-superia-o-investicie-v-afrike.

[7] SKVRNDA, F.: The Sociological Context of Creating the Theory of Security (in Slovak), In Slovenská politologická revue No. 4/2009 Year IX. pp 3-20 ISSN: 1335-9096 [on-line], cit [21.03.2011] available at: http://www.ucm.sk/revue/2009/4/skvrnda.pdf.

[8] MIKA, V., KELISEK, A.: Social Security from Point of View of Crisis Management. In: Socialni, ekonomicke, pravni a bezpecnostni otazky soucasnosti (Ceska a Slovenska republika na pocatku noveho milenia) [elektronicky zdroj] : 2. mezinarodni slovenskoceska konference, Praha : Soukroma vysoka skola ekonomickych studii, 2010, ISBN 978-80-86744-84-1. pp. 331-335.

[9] HNILICAN, V.: Trends in the Global Economy - Global Economic Risks and Possible Impacts (in Slovak), In: Ekonomicka univerzita v Bratislave, Fakulta medzinarodnych vztahov, Almanach 2004, Bratislava, Ekonom, ISBN 80-225-1883-2, pp. 78-85.

[10] VAZAN, M., KRAJCIK, D.: The Changing Role of Foreign Direct Investment in China's Economy (in Slovak), In: Zbornik Konkurenceschopnost ceskych podniku v podminkach rozsirene EU, VSE : Praha, 2006, ISBN 80-245-1056-1, pp. 246-251.

[11] FABUS, M.: Foreign Direct Investments and the European Union, In: Towards improving tourism atractiveness in Lithuania and Poland, Intern. Scientific conference. Kaunas, 2011, ISBN 978-9955-25-931-2

[12] MARKOVIC, A.: Chinese Expansion in Africa (in Slovak), In: Socialno-ekonomicka revue, Trencianska univerzita, Trencin : Fakulta socialno-ekonomickych vztahov, ISSN 1338-2195, 2010, No.. 1/2010, pp. 42-44.

[13] LESZCYNSKI, M., MIKA, V.: Social Security in New Approach to the State Security (in Polish), In: Acta Scientifica Academiae Ostroviensis, ISSN 1506-2864. - Z. 33, 2010, pp. 101-111. 